\title{
Economic and environmental analysis of five Chinese rural toilet technologies based on the economic input-output life cycle assessment
}

\author{
Hui Gao ${ }^{\text {a, b }}$, Chuanbin Zhou ${ }^{\text {a, }}$, Feng Li ${ }^{\text {a }}$, Baolong Han ${ }^{a}$, Xiuxia $\mathrm{Li}^{\mathrm{c}}$ \\ a State Key Laboratory of Urban and Region Ecology, Research Center for Eco-Environmental Science, Chinese Academy of Sciences, Beijing 100085, China \\ ${ }^{\mathrm{b}}$ College of Urban and Environmental Science, Xinyang Normal University, Xinyang 46400, Henan, China \\ ${ }^{c}$ School of Art and Design, Xinxiang University, Xinxiang 453000, Henan, China
}

\section{A R T I C L E I N F O}

\section{Article history:}

Received 8 April 2015

Received in revised form 20 November 2015

Accepted 25 December 2015

Available online 31 December 2015

\section{Keywords:}

Economic input-output life cycle

assessment model

Net present value

Rainwater harvesting

Urine diverting composting toilet

\begin{abstract}
A B S T R A C T
Building toilets are critical infrastructure to promote public health. The current sanitation technology in developed countries is based on diluting human excreta with large volumes of centrally provided potable water. This approach is a poor use of water resources and is also inefficient and energy intensive, which is not suitable for water-shortage rural areas of northern China. Therefore, comprehensive schemes of Chinese rural toilets, including standard flushing, rainwater harvesting flushing systems, urine separation and composting systems, were considered in this study by means of five scenarios simulation. Economic net present value method was adopted for economic analysis and economic input-output life cycle assessment model based on Chinese economic input-output table and life cycle database was developed for comparing energy consumption and greenhouse gas emission implications, aiming to guide the selection of toilet schemes. A mountainous village in Mentougou District of Beijing was taken as the example. Based on total cost and net present value method, the results showed that scenario 5 , namely urine diverting composting systems, outweighed the other four alternatives on the cost even in the different discount rates ranging from $0 \%$ to $10 \%$; scenario 3 , namely urine-diversion and potable water flushing toilet, was sub-optimal economic solution which net present value was negative when discount rate was over $8 \%$. This study also present scenario 3 's environmental superiority to scenario 5 on energy consumption and greenhouse gas emission. These two technologies were proved viable options for standard flushing toilet. Nevertheless, for another two scenarios of rainwater harvesting flushing toilets, they had higher amounts of investment, energy consumption and greenhouse gas emission due to the high investment on rainwater tank construction. Moreover, the vast majority of construction materials required high energy consumption and were carbon intensive sectors in China. Finally, some suggestions were given for the implementation of urine separation toilets and composting toilets in the practical application. Meanwhile, impact of the rising water price in selecting alternative technologies and tradeoff about the priority consideration for rural toilet technologies were analyzed in this study. Considering the great significance of rainwater harvesting toilet technology to save the water resources, measures of how much government should subsidize for guarantee its extension and motivation was discussed as well.
\end{abstract}

() 2016 Elsevier Ltd. All rights reserved.

\section{Introduction}

Facing a rapidly growing world population, the pressure on natural resources is continuously increasing, both on the local and

\footnotetext{
* Corresponding author. Tel./fax: +86 1062943807

E-mail address: cbzhou@rcees.ac.cn (C. Zhou).
}

global level. Simultaneously, a large number of people in developing countries, particularly in rural areas, have to be supplied with reliable systems for safe drinking water and sanitation to prevent the spread of infectious diseases and to overcome poverty.

The design of standard sanitation technologies in developed countries is based on the premise that excreta are waste and that waste is only suitable for disposal (Esrey et al., 2001). This "waste" is collected centrally in sewer pipes using centrally provided potable 
quality water as the transport medium. This approach is low efficient, energy intensive and also is a waste of water resource. Many drinking water systems lose as much as $20 \%$ of their treated potable quality water due to leaks in their pipe networks (Mehta, 2009). According to the Ministry of Housing and Urban-Rural Development (MOHURD), the electricity consumption of municipal wastewater treatment plant was 10 billion kilowatt-hours in 2013, accounting for $0.2 \%$ of China's total electricity use. And 10 billion Chinese Yuan (CNY) will be saved if power consumption is reduced by $10 \%$ (MOHURD, 2014).

Unlike traditional sanitation systems, the concept of ecological sanitation (EcoSan) relies on an environmentally and ecologically sound management of water, nutrient and energy fluxes (Otterpohl, 2002). Decentralized sanitation systems with source control of pollutants and reduced water consumption are, however, implemented throughout Europe, and certain aspects of their environmental benefits, economic viability and social acceptability have been investigated for different scales of implementation and wastewater loads (Dallas et al., 2004; Langergraber and Muellegger, 2005; Benetto et al., 2009). Rural areas in developing countries need especially to build decentralized sanitation infrastructure due to dispersed people and limited funds. Sanitation toilet such as rainwater-flushed-toilets, waterless urinals toilets and composting toilets not only reduce or eliminate the use of potable water but also improve rural health condition. From the views of system design, alternative selection and effect simulation, it was reported and discussed focusing on Ecosan (Henriques and Louis, 2011; Magid et al., 2006; Katukiza et al., 2012; Montangero and Belevi, 2008).

Ecosan and alternative sanitation concepts are widely ignored by public planning authorities, architects and engineers in China. In most rural areas of China, wastewater is typically conveyed in combined sewers that also convey storm water. According to the statistics of MOHURD, 96 percent of villages do not have drainage pipelines and sewage treatment systems. Centralized sewage treatment systems in Chinese vast rural areas are not appropriate. In addition, more than 450 million rural inhabitants continue to endure insufficient water supplies, rainwater harvesting will help to increase the self-sufficiency of rural areas in terms of water demand. China began to introduce some projects for ecological sanitation in the late 1990s, and domestic research is being in the initiative stage. As far as these achievements were concerned, they focused mainly on program design and optimization (Wang and Zhou, 2008; Zhou et al., 2008, 2010).

The practices of the Chinese ecological sanitation systems focus on rural areas and emphasize drinking water improvement, toilet amelioration, and excreta disposal, for example, urine diverting without flushing ecological toilet systems and excreta fermentation biogas systems.

Since the early 1970s, research on biogas production has been developed rapidly in China. Combined with regional situation, ecoagricultural models has emerged taking biogas as a core, including "Three in One" pattern combing the biogas digester with a pigpen and toilet in southern China, "Four in One" pattern combing the biogas digester, pigpen, solar greenhouse, and toilet in northern China, and "Five in One" pattern combing the biogas digester with solar-powered barns, water-saving irrigation system, water cellar, and toilet in northwest China. In addition, focusing on the effect evaluation of biogas-linked system, previous research (Chen et al., 2012; Chen and Chen, 2013a,b; Chen and Chen, 2014) made contributions on the study of energy shortage and global warming with the means of life cycle assessment and emergy analysis. However, household biogas use in rural China encounters constraints in straw fermentation, cold fermentation technology and management (Chen et al., 2010). Ecological toilet technology provides a new mentality for excreta treatment and water conservation under the current countryside situation. According to relevant data from the 2012 Chinese Rural Statistical Yearbook, the sanitary cover rate in rural areas is $71.7 \%$. In United Nations Millennium Development Goals (UNMDGs), the Chinese government promises that the cover rate is able to reach 75\% in 2015 years; therefore, China needs to increase efforts toward rural sanitation toilet construction.

Because centralized water and wastewater treatment systems are the norm, the life cycle impact of water treatment and supply (Stokes and Horvath, 2009; Vince et al., 2008; Friedrich et al., 2009) and wastewater treatment systems (Gallego et al., 2008; Zhang and Wilson, 2000) have been extensively studied. Nevertheless, there is only limited information available on the comparative life cycle impact of technologies that reduce potable water use in rural toilets. Some previous studies suggest that composting toilets and the use of rainwater to flush toilets may, in some cases, have a lower environmental impact compared to standard systems (Remy and Jekel, 2008; Chiu et al., 2009; Crettaz et al., 1999). How to select a appropriate and more sustainable technologies for rural area is urgent, however, at present, analysis and comparison of rainwater technology, composting toilet technology, and urine diverting fixtures technology have not been previously studied.

In previous studies, economic input output models was verified its advantage on obviating conventional life cycle on boundary assumptions, this model represented all the supplier relationships in the supply chain for industrial production. Therefore, some researches about economic and environmental analysis of industrial sector(Egilmez et al., 2013; Hsieh and Kung, 2013) and specific product (Jiang et al., 2014a; Nanaki and Koroneos, 2013; Jiang et al., 2014b; Wang et al., 2014; Wang and Yuan, 2014) appeared with Economic Input Output Life Cycle Assessment (EIO-LCA) as a tool. Application of this method was shown to be feasible. Nevertheless, owning to the different economic development levels, it had much different on the results of environment assessment, so the widespread use of Carnegie Mellon EIO-LCA software could not be completely followed by other countries and regions. In this study, we firstly attempted to build a model based on Chinese Economic Input-Output Table and Life Cycle Database, contributing to analysis and compare five alternative schemes with helping to select feasible rural toilet technology.

This study was supported by a demonstration pilot project on ecological settlement transformation, which integrated ecological engineering, including ecological toilets, organic waste reclamation management and sewage treatment. This project aimed to improve the ecological environment and promote the ecological quality of the Chinese northern rural area. As a part of the project research results, a mountainous village named Shuiyuzui in the Mentougou District in Beijing was selected as a case study. Environmentally friendly, affordable and simple operation eco-toilet technology was explored and applied to reduce none-point pollution from the source. Water shortages and dispersed population are problems in this area, as in other Chinese northern rural regions. Planning and building eco-toilet should be based on local natural conditions, and then water-saving and decentralized eco-sanitation technologies need to be prioritized. Alternative sanitation technologies, such as rainwater-flushing-toilets, urine-diversion toilets and composting toilets, can reduce or eliminate the use of potable water to flush toilets. These alternative technologies can have good technical performance (Ghisi, 2006; Gajurel et al., 2003), and if they have comparatively lower costs and environmental impact, they will replace the current potable water based sanitation systems in the future.

The goal of this study was to investigate the cost, energy consumption and global warming implications of the use of standard and alternative sanitation technologies in a mountain village. The 
alternative technologies considered was rainwater harvesting to flush standard toilets and urinals, potable water to flush feces and waterless urinals, rainwater harvesting to flush feces and waterless urinals, and composting toilets and waterless urinals. This study adopted Economic Net Present Value (ENPV) method for economic analysis, and economic input-output life cycle assessment (EIOLCA) model was used to compare environmental effect based on Chinese Economic Input-Output Table and life cycle database. The technologies were evaluated for the manufacturing and operation life cycle phases of five scenarios, calculations were modeled on new socialist countryside buildings in the Mentougou District, Beijing. Economic and environmental benefits were compared and evaluated in this study, and the results offered a theoretical basis for improved water supply and sanitation for new rural reconstruction in North China with insufficient water supply.

\section{Methods}

\subsection{Site description}

The mountainous village in this study is located to the west of Beijing, $39 \mathrm{~km}$ away from the city. In accordance with the requirements of the program design, 150 new houses were designed to be built the traditional single-storey structures cottage of North China. There were 592 people in this village with average 4 people per household. At $3.5 \mathrm{~m}$ high, the new house possessed a roof area of 120 square meters. A toilet (length, width and height of $1.5 \mathrm{~m}^{*} 2.1 \mathrm{~m}^{*} 2.0 \mathrm{~m}$ ) was built in the corner of each courtyard with one squat and one urinal, located $6 \mathrm{~m}$ from the dwellings. Current standards for toilets and urinals in China require $6.0 \mathrm{~L}$ and $4.0 \mathrm{~L}$ per flush, respectively (China National Standardization Management Committee, 2005).

\subsection{Scenario considered}

Five scenarios were compared (Fig. 1). The base scenario (scenario 1) was the standard potable water flushing toilets, and the wastewater from flushing was discharged into the sewage treatment system. The other four scenarios were alternatives to scenario 1. Standard toilets and urinal fixtures were installed in scenario 1. These require $6.0 \mathrm{~L}$ and $4 \mathrm{~L}$ of potable water per flush, respectively. In scenario 2 and scenario 4, rainwater was harvested and used for flushing. Scenarios 3, 4, and 5 employed different toilet fixtures from scenario 1 and scenario 2, which allowed for the separation of feces and urine. Urine contains 80 percent of the nutrients in human excreta, and there are less pathogens in urine (Remy and Jekel, 2008). If undiluted urine is collected, it can be used as an efficient fertilizer with simple treatment. Urine from waterless urinals was managed and stored separately in scenarios 3, 4 and 5. Scenario 3 was the same as scenario 4, except rainwater flushing was used. Scenario 5 was a composting system that required no water to operate. Composting toilets are used more commonly in developing countries (Morgan, 2007), especially in rural areas.

When harvested rainwater was used to flush toilets, the need for centrally provided potable water may be reduced or eliminated for toilet flushing purposes, although the wastewater flows would remain the same. Composting toilets do neither require water nor generate wastewater, consequently, become an alternative and decentralized approach to the management of human excreta. In a composting toilet system, human urine, feces were separately collected by gravity in storage tank. While potable water would still be required for hand washing, the composting toilets did not require any water for flushing and there were little wastewater discharge to municipal water and sewer systems. The compost from dry toilets and urine from waterless urinals were both nutrient-rich resources and could be applied as a fertilizers or soil conditioners, but they needed to be managed safely due to the presence of pathogens. The urine should be stored for at least six months before being considered hygienically safe to fertilize food and fodder crop which were processed before consumption (Langergraber and Muellegger, 2005). Iron covers were installed on the composting tank with black color, considering their heat-absorbing capability, to raise the temperature of the manure pile to kill pathogens. The management of compost and urine were not within the scope of this study because science and performance-based approaches for management and disinfection of the human compost are not fully established; researches are ongoing in this area (Vinneras et al., 2003; Winker et al., 2009; Niwagaba et al., 2009).

\subsection{Life cycle assessment}

The life cycle assessment (LCA) was used to compare the five different design scenarios. LCA is an important tool for authorities and industries in order to compare alternative product process or services. This coherent comparison attained on the base of the same service or "function". In this study, the functional unit was the

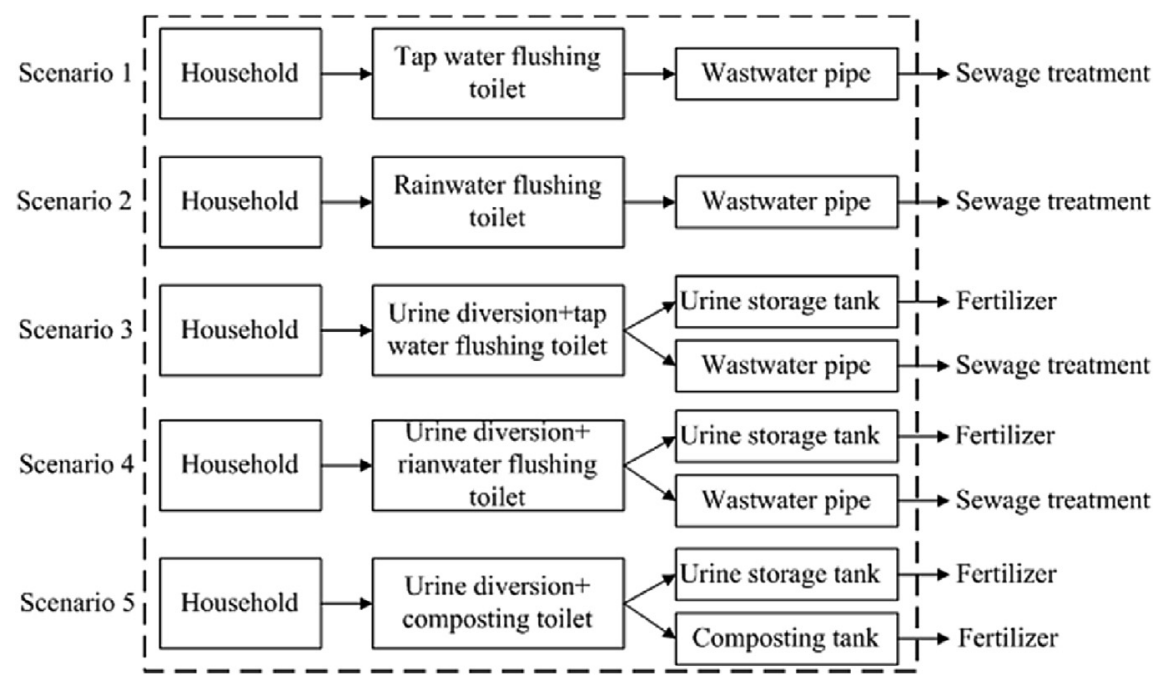

Fig. 1. Five design scenarios modeled for rural toilets in this study (the dashed box indicates research boundary). 
provision of sanitation services for 600 people (150 households of 4 people). Only the manufacturing and operational phases were considered in our study. Some literatures concluded the construction and end of life management phases were negligible for both buildings and water infrastructures (Scheuer et al., 2003; Ortiz et al., 2007) and were not include in our analysis. The compost product from composting toilet and urine from storage tank could be further processed and used as fertilizer. However, these materials were excluded from this study according to the scope and corresponding functional unit of the study.

There are basically two categories of LCA methodologies: one is the conventional process-based LCA, which stresses energy and material flow in a manufacturing process, and the other is the input-output based LCA, which links environmental data to the manufacturing process. Hendrickson and his colleagues (1998, 2006) proposed the Economic Input-Output Life Cycle Assessment (EIO-LCA) method to analyze the environmental impact of products and services in the production chain. All products and services are classified to a specific sector. This method provides a comprehensive estimate of a sector's or a group of sectors' energy demand and emissions. The EIO-LCA method is based on assumptions of homogeneity and proportionality. The former means whatever the category of the product, the environmental impact is proportional to its price in the same sector. The latter refers to the product's input being proportional to its output in the same sector (Baral and Bakshi, 2010). EIO-LCA can make up the shortage of truncation errors in process-based LCA and is suitable for comparative evaluation of similar products from different sectors but not for different or new products from the same sector (Joshi, 1999).

The adaptation of EIO-LCA practices could significantly increase the applicability of screening LCAs in strategic environmental management (Junnila, 2006). One of the key benefits of using an EIO-LCA model is that it provides the complete supply chain of economic activity needed to manufacture any good or service in the economy (Matthews and Small, 2000). Previously, the EIO-LCA (model developed at Carnegie Mellon University free on the web site) method was used in comparing standard roofs to green roofs with U. S.-based data (Muga et al., 2008). Based on the actual Chinese situation, some researchers developed models suitable for China (Ji et al., 2011; Li et al., 2011; Huang et al., 2012). In this study, the EIO-LCA method was used to estimate the energy demand and carbon dioxide equivalence emissions $\left(\mathrm{CO}_{2} \mathrm{e}\right)$ for the manufacturing and operating phases of the five sanitation design scenarios. The ecological input-output model used was as follows:

$B=R(I-A)^{-1} y$

where, $B$ was the final demand, $y$ caused the energy demand and GHGs emissions $\left(\mathrm{CO}_{2} \mathrm{e}\right)$ from all sectors, $B_{i j}$ was the element of matrix $B$ ( $i$ was the number of the sector providing the product or service, $j$ was the number of the sector using the product or service, $i=1,2 \ldots \mathrm{n}, j=1,2 \ldots \mathrm{n}$, and $n$ was the number of the sector in the input-output tables). The sum of each row vector in matrix $B$ represents the amount of GHGs emissions and energy consumption of sector $i$ during the process of product generation and service provision. The sum of each column vector in matrix $B$ was the implicit amount of GHGs emissions and energy consumption of sector $j$ during the process of using the product and service provide by sector $i$. $R$ was a diagonal matrix, and its diagonal element $R_{i}$ showed the amount of GHGs emissions and energy consumption of one unit of sector $i$. $I$ was an identity matrix. A was a direct absorption matrix with element $A_{i j}$, which meant that sector $i$ provided the output for sector $j$ with the addition of one unit final demand. The Chinese Input-Output Tables 2007 (National
Economic Accounting Department of Chinese State Statistics Bureau, 2009) supplied the reference for the $A_{i j}$ value. $y$ was a column vector of the final demand with element $y_{j}$, which represent the ultimate application of the product and service of sector $j$ (including the ultimate consumption, capital formation, input and output). The value of $y_{j}$ was the price column of the inventory in the Appendix supplementary data of Table $\mathrm{S}_{1}$. Matrix $\mathrm{R}$ was related to economic development and pollution control level. Chen and Chen (2010) concluded a database of carbon emissions and resource use in a detailed 135-sector inventory by Chinese economy 2007. The research result provided reference for the values of diagonal element $R_{i}$ in Matrix $\mathrm{R}$, which could be seen in the Appendix supplementary data of Table $S_{2}$.

EIO-LCA was used to analyze the direct and indirect effect of the resources related to each of the scenarios. For the expenditure in an economic sector, EIO-LCA calculated the relative emissions due to the expenditure in that sector, as well as in the supply chain. The monetary values used in the model represent the value of the currency in the year of the model (2007). The consumer price index (CPI, 2013) was used to convert the current prices to 2007 values before the dollar amounts were input into the EIO-LCA model. MATLAB software was applied to perform the matrix computation.

\subsection{Potable water demand and wastewater volume estimation}

For the life cycle inventory of the operation phase, it was essential to estimate the potable water required and wastewater generated. The potable water demand was estimated assuming that a per person urinated four times a day for a total of $1.5 \mathrm{~L}$ and had one excrement each day (Berndtsson, 2006). The volume of urine and flush water per year was calculated for 600 inhabitants living in the building 365 days a year given estimated urine and flush water amounts of $0.879 \mathrm{~m}^{3}$ and $4818 \mathrm{~m}^{3}$. Assuming that wastewater discharge was equal to the amount of flush water, scenario 1 and scenario 2 had the same discharge of $4818 \mathrm{~m}^{3}$.

The rain water tanks in scenarios 2 and scenario 4 were sized based on the roof area and monthly precipitation data for Beijing, Mentougou. According to Beijing's Code for Design of Storm water Management and Harvest Engineering (CDSMHE), this study applied the following formulas to calculate the roof rainwater

$Q=\varphi^{*} \lambda^{*} \beta^{*} F^{*} H$

where $\Psi=$ roof rainwater runoff coefficient, $\lambda=$ seasonal deterioration rate, $\beta=$ initial discarded water coefficient, $F=$ roof area, and $H=$ precipitation. According to CDSMHE, and in consideration of Beijing's season and climate condition, this research used $\Psi, \lambda, \beta$, $F$, and $H$ values of $0.9,0.8,0.87,120 \mathrm{~m}^{2}$ and $584 \mathrm{~mm}$, respectively, and the full-year water resources gross was $43.89 \mathrm{~m}^{3}$. For guaranteed supply, rainy season water accounted for 80 percent of the annual precipitation (which was $35.11 \mathrm{~m}^{3}$ ). Each household consumed a volume of $26.28 \mathrm{~m}^{3}$ flushing water in one year, in other words, the rainy season water could satisfy the yearly demand of flush water. Dry season rainwater was $9.78 \mathrm{~m}^{3}$, and the dry season lasted almost half of the year (from September to the next February). Because this sizing method was a demand-basedlargest-storage approach, the rainwater tank sizes were different for each scenario. Scenario 2 required $13.14 \mathrm{~m}^{3}$ flush water in the dry season. Hence, its rainwater tank size was $3.36 \mathrm{~m}^{3}$. Scenario 4 required $8.76 \mathrm{~m}^{3}$ flush water in the dry season, and its rainwater tank size was $1.02 \mathrm{~m}^{3}$. Steel and waterproof concrete were the most common building materials for rainwater tank, and considering the $1.2 \mathrm{~m}$ permafrost underground in the winter and rainwater freezing, the rainwater tank sizes of scenario 2 and scenario 4 were $2 \mathrm{~m}^{*} 1.5 \mathrm{~m}^{*} 2.7 \mathrm{~m}$ and $1 \mathrm{~m}^{*} 1 \mathrm{~m}^{*} 2.5 \mathrm{~m}$ (length, width and depth), 
respectively. Compared to scenario 1 , a $73 \%$ reduction in potable water demand was possible when using the urine diverting toilets in scenario 3 and scenario 4.

\subsection{Life cycle inventory of the manufacturing phase}

The life cycle inventory for all five scenarios was given in the Supplementary material. The costs of all inventory items were obtained from ten vendors for the mean value in different regions of Northern China. Scenarios 1 and 2 installed the similar toilet fixtures and urinals as standard toilet. For separating urine, special toilets had been developed with a front bowl collecting the urines and rear bowl collecting the feces in scenarios 3, 4 and 5 and scenarios 5 had different dry urine-diverting toilets from scenarios 3 and 4. Compared to scenarios 1 and 3 , in order to storage and transport rainwater, additional equipment was included in scenarios 2 and 4, such as rainwater tanks, pumps and pipes (for conveying rainwater from the tank to the toilets). On the purpose of unified construction material and reduce cost, the rainwater tanks were built with steel, concrete and waterproof material. The required pipe lengths were estimated assuming that the rainwater $\operatorname{tank}(\mathrm{s})$ would be placed between the house and toilet. A floating tank filter was included to deliver water from a depth slightly below the water surface in the tank and filter this water before it out of the tank. A plastic tank of $1 \mathrm{~m}^{3}$ volume was under ground for urine storage, and a pump was connected to the filter intake. Scenario 5 included a composting system, which was widely applied in Guangxi and Jilin provinces in China. The system included porcelain toilet fixtures, waterless urinals, composting tank (brick structure), urine-storage plastic tank, ventilating pipe from composting tanks, a $220 \mathrm{~V} 12 \mathrm{~W}$ fan for venting odors, and a black iron plate to keep the compost warm. Composting tanks $\left(1.2 \mathrm{~m}^{*} 1 \mathrm{~m}^{*} 0.8 \mathrm{~m}\right)$ were assumed to be placed in the basement of the buildings.

The materials in the inventory were assumed to be replaced after their effective life time. The toilets were considered to be replaced after 35 years and pumps after every 20 years (Kirk and Dell'Isola, 1995). Based on the requirements of the Chinese Norm of Civil Building Design (CNCBD), rural toilets have a service life time of 25 years. In this study, we assumed the service life time of the toilets to be 25 years. All scenarios were analyzed for 25 years.

\subsection{Life cycle inventory of the operation phase}

For scenario 1 and 3, the use of potable water and wastewater treatment service were included in the operation phase. The annual rainwater volume collected from the roof satisfied the need for flushing the fixtures, so there was only wastewater treatment service in the operation phase of scenario 2 and 4 , while scenario 5 was a waterless system that required no water to operate. The wastewater treatment services may have greater emissions and energy requirements than water treatment and supply. According to Beijing's current water price, this study introduced different prices for potable water and wastewater treatment. This distinction could be modeled in the calculation. Booster pumps were demanded in scenarios 2 and 4 for delivering water from the rainwater tanks to the toilet. The water tanks collected rainwater after abandoning part of the initial flow with pipe transportation. Then, poly-aluminum chloride (PAC) flocculent was dosed to accelerate the precipitation, that is, the tank played the role of storage, regulation and precipitation. Urine management and the dosing flocculent were both neglected in this study.

For scenario 5, the electricity consumption for exhaust fan to vent the air was included in the operation phase of the inventory. In some composting toilets, additives were use to improve the affecting condition and reduce odors, such as sawdust, wood ash, lime, straw etc, which had effect on adjusting carbon to nitrogen ratio and $\mathrm{pH}$ and enhancing the level of aeration. Additives and other processes for managing the compost were not included in the life cycle inventory.

\subsection{Economic analysis}

The economic net present value (ENPV) is the absolute indicator reflecting net construction for the national economy (Belli et al., 2001). ENPV analyses were used to evaluate the economic implications of the alternative scenarios. When comparing which project to invest in, ENPV is often preferred over other investment criteria by financial officers (Brealey, 2012). This approach assumes to invest in projects with positive NPV. In this study, the NPV of scenarios $2,3,4$, and 5 were calculated with respect to the cash flows of scenario 1 using the following equation:

$N P V=\sum_{t=0}^{25} C_{t} /\left[(1+r)^{\wedge} t\right]$

where $t=$ time (years), $r=$ discount rate (initially $0 \%$; varied from $0 \%$ to $10 \%$ for the sensitivity analysis), and $C_{t}=$ cash flow of the evaluated scenario minus the cash flow of the standard scenario for $t$.

\section{Results}

\subsection{Economic analysis}

The costs for five scenarios for a lifetime of 25 years were shown in Table 1. The total cost order of the scenarios from highest to lowest was scenario $2>$ scenario $4>$ scenario $1>$ scenario $3>$ scenario 5 . The manufacturing cost of scenario 2 was almost four times that of scenarios 3 and 5 . Scenarios 3 and 5 had comparable initial costs. Due to the expensive consume on the construction of rainwater tanks, the manufacturing costs of scenarios 2 and 4 were very high compared to those of scenarios 1,3 , and 5 . For scenario 1, the annual operation cost paid for water and wastewater services was $19300 \mathrm{CNY}$, the cost was a little higher than scenario 2 which saved the water rate partially, but this cost almost corresponded to the triple or quintuple cost of scenario 3, 4 and 5. Over the whole life period, scenario 1 had a higher operation cost

Table 1

Costs of five toilet technologies over a 25 year period.

\begin{tabular}{|c|c|c|c|c|c|c|c|c|c|c|}
\hline \multirow[t]{2}{*}{ Cost (CNY) } & \multicolumn{2}{|c|}{ Scenario 1} & \multicolumn{2}{|c|}{ Scenario 2} & \multicolumn{2}{|c|}{ Scenario 3} & \multicolumn{2}{|c|}{ Scenario 4} & \multicolumn{2}{|c|}{ Scenario 5} \\
\hline & $10^{4} \mathrm{CNY}$ & $\%$ & $10^{4} \mathrm{CNY}$ & $\%$ & $10^{4} \mathrm{CNY}$ & $\%$ & $10^{4} \mathrm{CNY}$ & $\%$ & $10^{4} \mathrm{CNY}$ & $\%$ \\
\hline Initial $\mathrm{MC}^{\mathrm{a}}$ & 22.35 & & 99.30 & & 35.55 & & 70.16 & & 35.05 & \\
\hline Annual $\mathrm{OC}^{\mathrm{b}}$ & 1.93 & & 1.81 & & 0.53 & & 0.49 & & 0.39 & \\
\hline Total MC & 22.35 & 31.7 & 99.3 & 68.7 & 35.55 & 72.8 & 70.16 & 85.1 & 35.05 & 78.2 \\
\hline Total OC & 48.25 & 68.3 & 45.25 & 31.3 & 13.25 & 27.2 & 12.25 & 14.8 & 9.75 & 21.8 \\
\hline Total & 70.6 & 100 & 144.55 & 100 & 48.8 & 100 & 82.41 & 100.0 & 44.8 & 100 \\
\hline
\end{tabular}

a Manufacturing cost.

b Operational cost. The lifetime operational and manufacturing costs are from the cash flows using a $0 \%$ discount rate. 
(accounting for 68.3\%)than manufacturing process cost (accounting for $31.7 \%$ ), whereas the other four scenarios had the reverse results that manufacturing cost occupied more than $65 \%$ of the total cost.

Compared to the standard toilets, rainwater and composting based systems possessed higher manufacturing costs, while their annual operational costs were lower. The cash flows of rainwater based systems were sensitive to local climate condition, fixture flushing demand, and water utility rates, therefore, they would vary for different locations. With the increasing energy prices, aging infrastructure, and shortages of available funds to maintain them, water utility prices were expected to increase. As water utility prices increase, the operational cash flows for scenario 1 would also increase, making the rainwater cases and composting system more beneficial. The initial cost for the construction of rainwater tanks was the most expensive component of the rainwater harvesting scenarios. The cash flow of rainwater system would changed while different material selected, this study chosen steel and cement from economic, reliable and practical views.

The 25 year cost of scenario 1 was $706000 \mathrm{CNY}$ (Table 1), in comparison to scenario 1 at a $0 \%$ discount rate, scenarios 3 and 5 resulted in a positive NPV for the 25 year analysis (Fig. 2). Cash flow began to return after 8 and 9 years for scenario5 and scenario3, respectively. The composting scenario had the highest NPV of approximately $300000 \mathrm{CNY}$. The manufacturing cost of scenarios 3 and 5 were roughly equal, but scenario 5 had a relatively lower operation cost. Therefore, scenario 5 achieved a return around one year earlier than scenario 3. Scenarios 2 and 4 did not result in a positive NPV within 25 years. This was because of the investment in anti-leakage reservoirs, water pumps and types of pipes for the construction of the rainwater system. Scenario 2's manufacturing cost was more than four times that of scenario 1 , rainwater replaced potable water for flushing, the savings from the water price in the operation process of scenario 2 was offset by the power consumed by the pump, therefore, scenario 2's operation cost was not significantly reduced compared to scenario 1 . Scenario 4's manufacturing cost was three times higher than scenario 1 with a relatively smaller rainwater tank (Table 1), but its operation cost accounted for 25 percent of scenario 1 and total cost of scenario4 was 118100 CNY higher than scenario1. From an economic point of view, neither of these two alternatives was appealing. Based on the cash flows of all scenarios, the composting case (scenario 5) was the best alternative, and the rainwater flushing case (scenario 2) was the worst investment alternative for replacing standard toilets. In addition, urinediversion and potable water flushing toilet (scenario 3) was relatively optimal alternative besides the composting system.

The NPV's of all scenarios decreased with a rise in the discount rate (Fig. 3), especially for scenario 3, 4 and 5. The composting system showed the highest NPV. Instead, scenario 2 revealed the lowest for all the alternatives. The NPV of scenario 2 and 4 were negative for all discount rates due to their higher manufacturing cost and annual lower operating cost than scenario 1 . The difference in the NPV between scenario 2 and 4 decreased as the discount rate increased. At an 8\% discount rate, the NPV of scenario 3 was 16200 CNY, whereas appeared a negative value at $10 \%$ discount rate. The composting scenario kept positive even at $10 \%$ discount rate, therefore scenarios 5 was beneficial compared to scenario 1 and could be considered as alternative scenarios at all discount rate. As an alternative, scenario 3 was no longer the optimal ones when discount rate was over $8 \%$.

For scenario 3, 4 and 5, if the transport and management of the urine storage and composted end product were included, some factors, like transportation of the compost and urine from the site to a farming area, sale of the compost, and emissions due to the storage and composting process, etc, would impact the cost, energy and carbon emissions. Furthermore, organic fertilizer generating from urine and compost in urine separation toilets produced indirect economic benefit, and would change the NPV of scenarios 3 , 4 , and 5, either. In addition, urine separation toilet systems and composting toilet systems present other issues that would affect whether to invest in such projects. For example, bad odor, acceptance by users and operational issues needed to be considered prior to selection of these scenarios (Magid et al., 2006).

\subsection{Energy use}

In Fig. 4, the order of scenarios based on highest to lowest total energy demand was: scenario $2>$ scenario $4>$ scenario $1>$ scenario $5>$ scenario 3 , which was different from cost order. Scenario 3

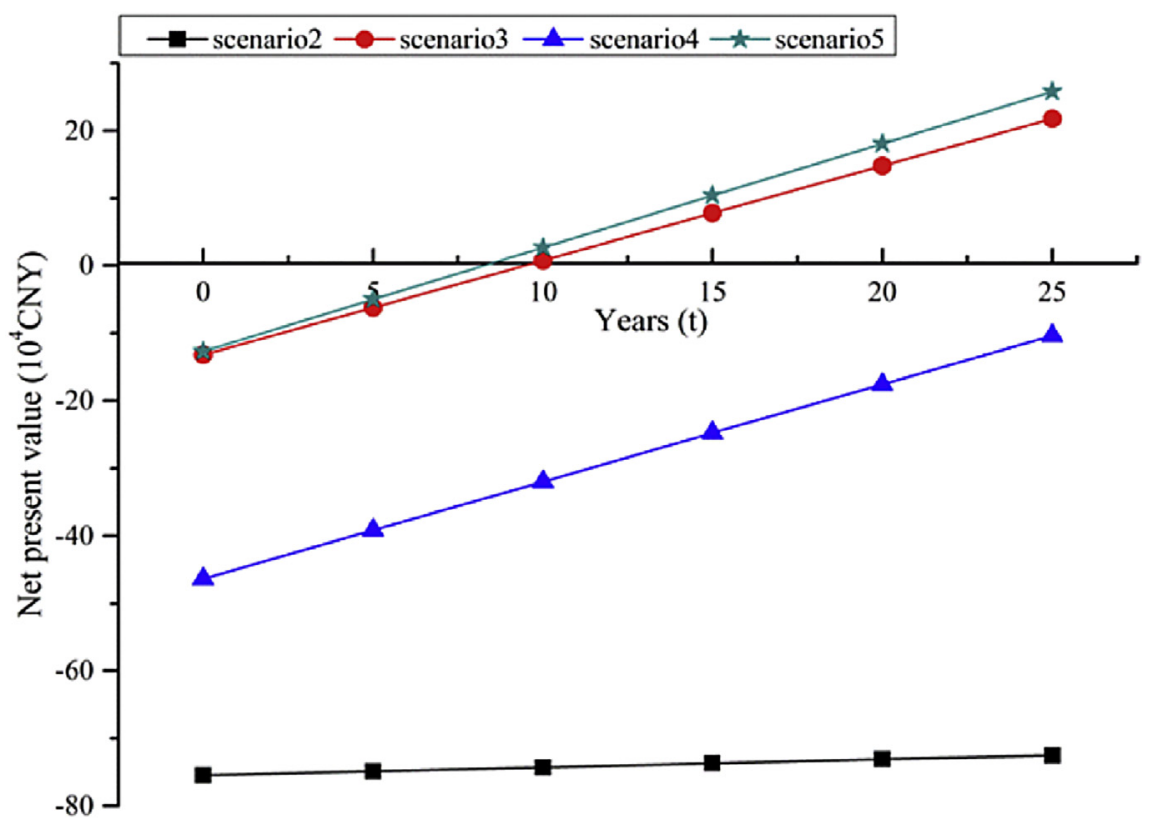

Fig. 2. Net present value of alternative scenarios from a 25 year analysis with a $0 \%$ discount rate. 


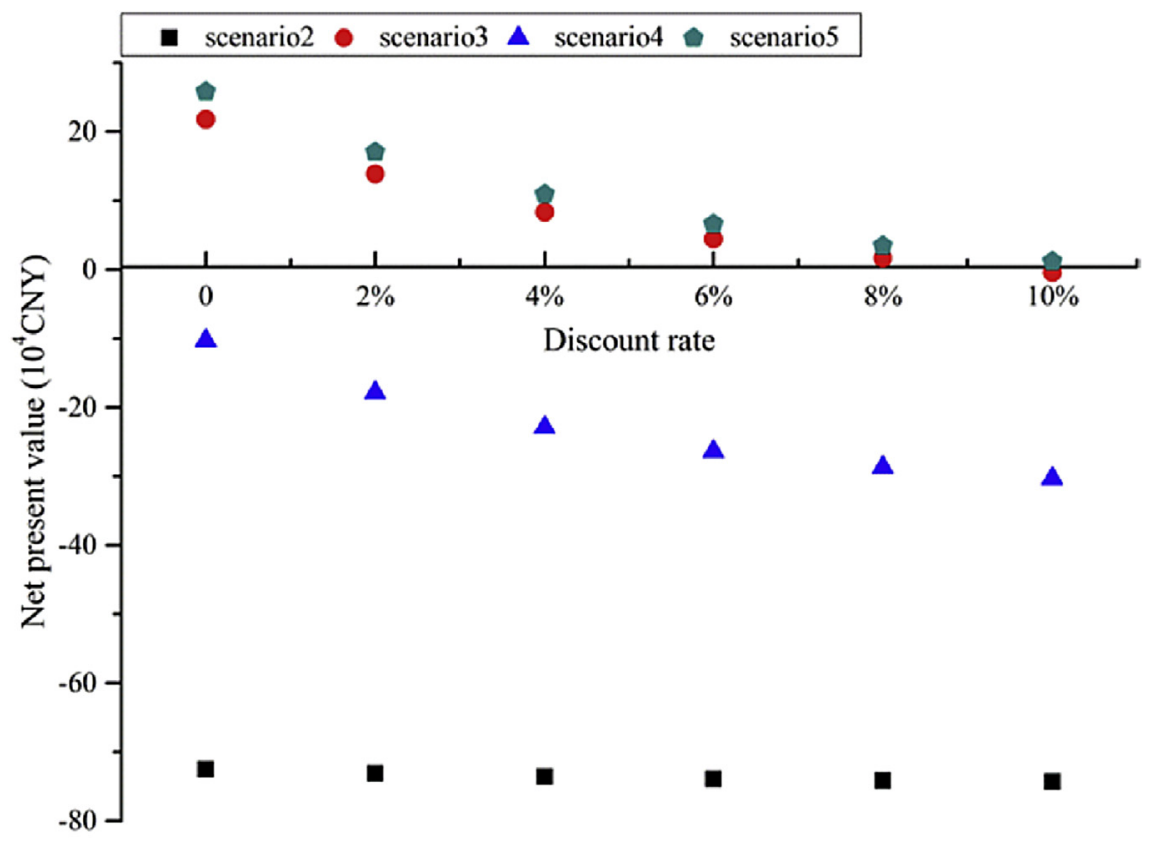

Fig. 3. Variations in net present value of alternative scenarios with different discount rate.

possessed the least amount of energy consumption instead of scenario 5. Energy use of manufacturing phase was roughly equivalent (approximately $9.3 \mathrm{E}+12 \mathrm{~J}$ ) in scenario 3 and 5 . The energy demand of scenario 3 was primarily from wastewater use, whereas that of scenario 5 was from electricity consumption, and (on a unit cost basis) electricity consumption results in almost ten times more energy demand than water consumption in Chinese economy (seen sector code 92 and 94 in the Appendix supplementary data of Table $\mathrm{S}_{2}$ ). Moreover, the operational cost was slightly different (132500 CNY and 97500 CNY, respectively). So, scenario 3 was superior to scenario 5 on energy consumption. In addition, energy use in manufacturing stage occupied a greater proportion (above 70\%) than operating phase in other four alternatives (Fig. 4). Whereas, operating phase accounted for over half of the total energy use in scenario 1.

The cost and energy payback periods of the scenarios were different as well. The initial and annual energy demand for scenarios 3 and 5 were similar. Scenario 3 had a payback time of 14.3 years, and scenario 5 had a payback time of 20.9 years (Fig. 5). For scenarios 3 and 5 , the energy payback period was longer than the cost payback period. This change was primarily due to the energy intensity level of the manufacturing phase of these two scenarios. The total manufacturing energy use of scenarios 3 and 5 was about two times greater than scenario 1 . However, the annual

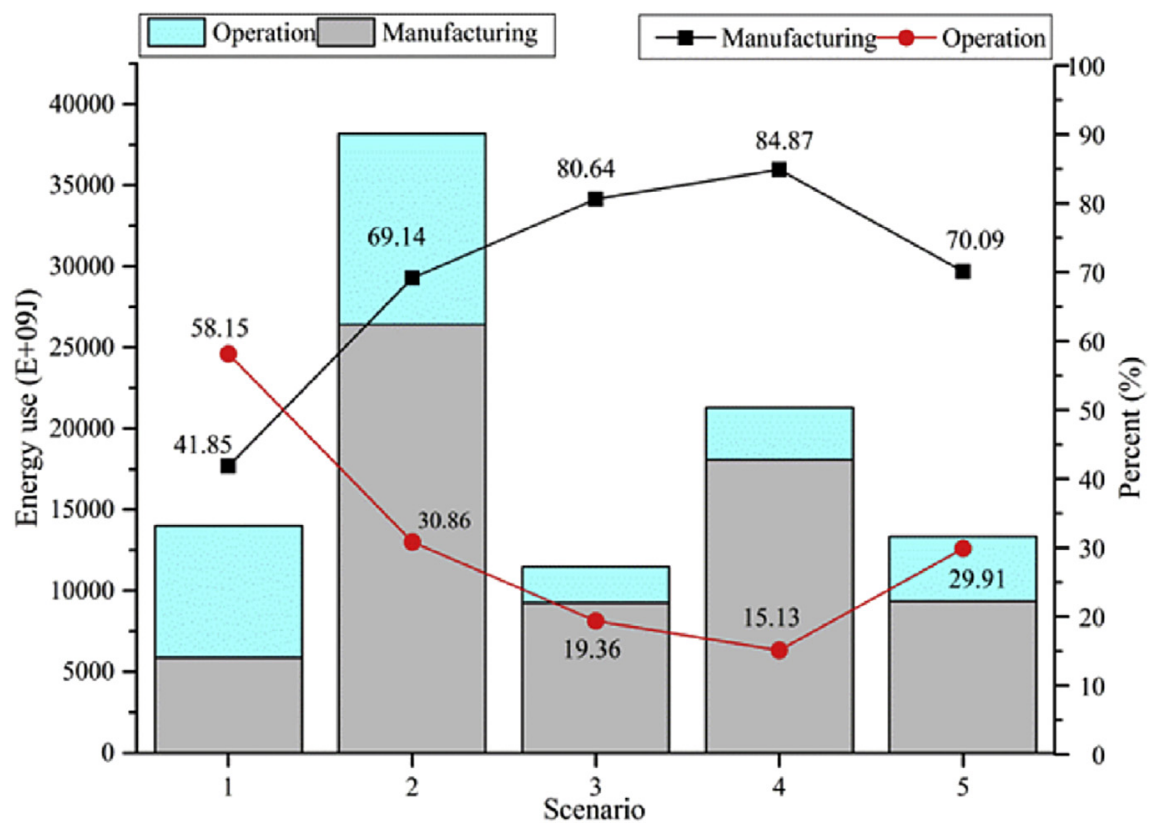

Fig. 4. Energy consumption in the manufacturing and operational phases of the technologies over a 25 year period ( $\mathrm{J}=\mathrm{Joules})$. 


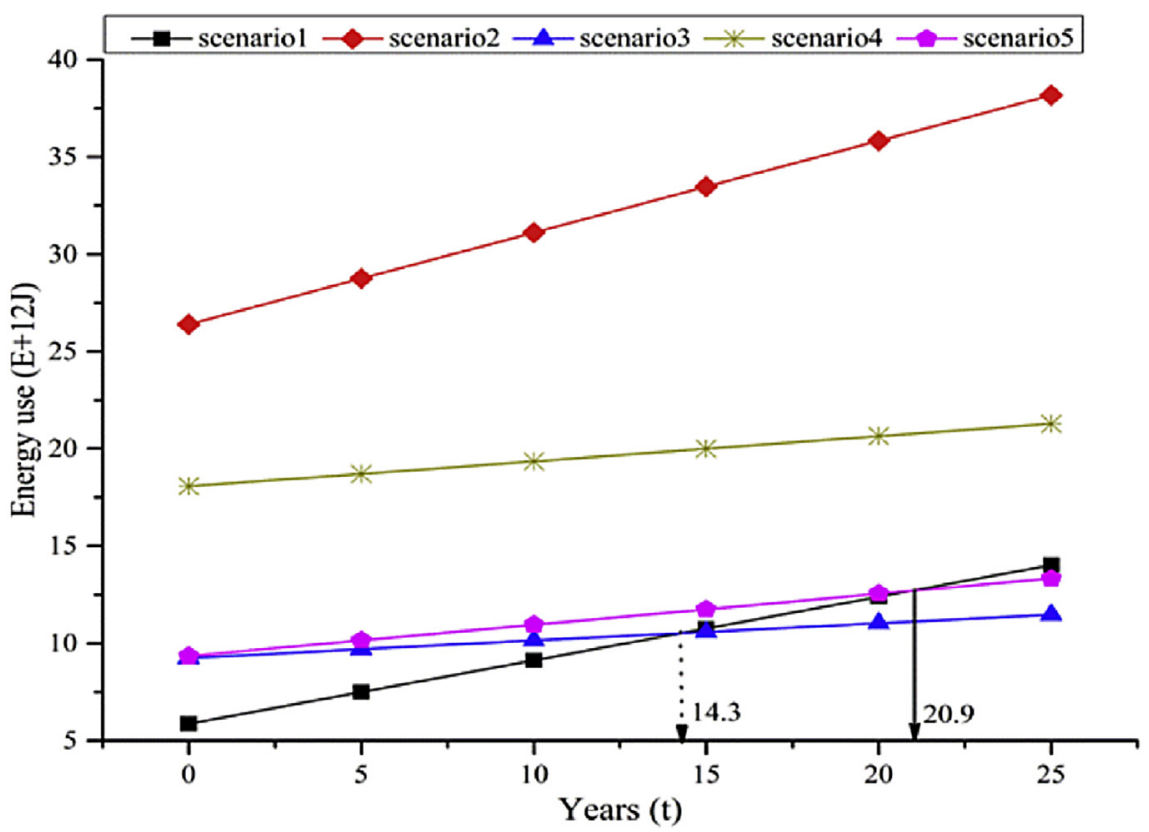

Fig. 5. Total energy consumption in process of 25 years of the technologies ( $\mathrm{J}=$ Joules).

energy demand of scenarios 3 and 5 was less than scenario 1 (Fig. 5).

Both the energy and cost analyses showed that the rainwater harvesting cases (scenarios 2 and 4 ) were not a viable option. For scenario 2, the need for large volume rainwater tanks and wastewater restricted energy payback. Rainwater harvesting with urine separation (scenario 4) had lower operation energy, but its manufacturing energy was three times higher than scenario 1. Therefore, over a period of 25 years, these two lines did not intersect the line of scenario 1 in Fig. 5, which indicated that a payback period did not occur.

\subsection{Greenhouse gas emission}

From Fig. 6, over a 25-year operational life, the carbon footprint was the highest for scenario 2 (5929 tons carbon dioxide equivalent, $\mathrm{CO}_{2} \mathrm{e}$ ). Scenario 4's 25 year carbon footprints were 3327 tons $\mathrm{CO}_{2}$ e. Scenario 4 required $73 \%$ less potable water compared to scenario 2 . This reduction in water resulted in a $44 \%$ carbon savings. The rankings of the other scenarios based on $\mathrm{CO}_{2} \mathrm{e}$ were the same as those based on the total energy: scenario $1>$ scenario $5>$ scenario 3. Scenario 3 ( 1787 tons $\mathrm{CO}_{2} \mathrm{e}$ ) had a much smaller carbon footprint than any of the other technologies. Compared with Fig. 4, some changes were found that the proportion of GHG emissions decreased in the operational phase, especially in scenarios 2 and 4. The reason for this change lied in the use of brick, steel rebar and waterproof material in the manufacturing phase increased the $\mathrm{CO}_{2} \mathrm{e}$ emission. These sectors are carbon intensive. They have larger $\mathrm{CO}_{2} \mathrm{e}$ emissions than the water production sector and the electric power production sector in Chinese economy. Based on the Appendix supplementary data of Table $S_{2}$, on a unit cost basis (i.e., for every CNY of product), the use of brick and steel emitted almost eight times and six times more $\mathrm{CO}_{2} \mathrm{e}$ than electric power production, respectively. Meanwhile, scenarios 2, 3, 4, and 5 had a larger proportion of manufacturing cost than operation cost (Table 1 ).

The $\mathrm{CO}_{2} \mathrm{e}$ payback periods for all four scenarios were similar to that of energy (Fig. 7). Scenario 3 had a payback time of 13.4 years, and scenario 5 had a payback time of 22.1 years. Rainwater harvesting technologies (scenario 2 and 4) still didn't realize payback. For scenario3, the $\mathrm{CO}_{2}$ e payback periods changed shorter than the energy payback period, the reverse was observed for scenario5. This change was primarily due to the proportion of operational $\mathrm{CO}_{2} \mathrm{e}$ emission over a 25-year life. The GHG emission of scenario 3 was primarily from wastewater use, whereas that of scenario 5 was from electricity consumption, and (on a unit cost basis) electricity consumption results in almost four times more emission than water consumption in Chinese economy (seen sector code 92 and 94 in the Appendix supplementary data of Table S2). Moreover, the operational cost was little different (seen Table 1).

\section{Discussions}

\subsection{Sensitivity analyses}

The management of uncertainty is significant in establishing LCA as a rigorous and reliable tool to inform decision-making. While quantitative uncertainty analysis is not attempted in this paper, on account of the difficult acquisition and limit amount of raw data, this study comments here on qualitative aspects of geographic and aggregation/price uncertainty. Developing models and data to address these uncertainties is a task for future work.

Geographic uncertainty refers to the effect of regional variations in process characteristic. Village data was applied for process LCA and national sector data for EIO-LCA. Beyond that, the cost data used for the inverter was adjusted from the price data (cost data is hard to find). There is uncertainty associated with the increasingly national variation features of material supply chains. Since the EIO model considers a static and linear state of the economy, and provides comprehensive and nationwide averages of the energy and $\mathrm{CO}_{2} \mathrm{e}$ emission effects. Thus, it is not able to simulate long-term effects. In addition, there is also aggregation and price uncertainty associated with the EIO-LCA component. Previous studies (Katinas and Markevicius, 2006; Williams et al., 2009; Lo et al., 2005) addressed uncertainty inherent of aggregation in EIO-LCA model, including the summing of data from different manufacturers producing the same product into an aggregate process, and from the 


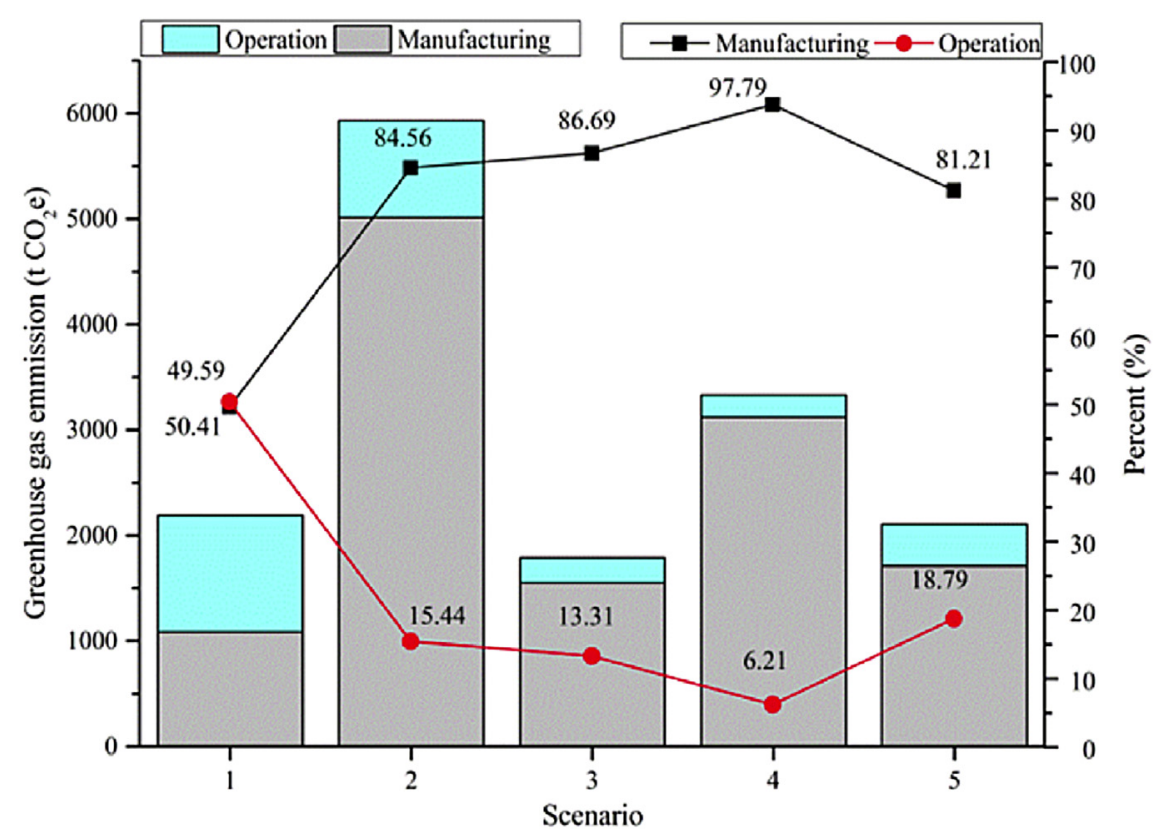

Fig. 6. Greenhouse gas emissions in the manufacturing and operational phases of the technologies over a 25 year period.

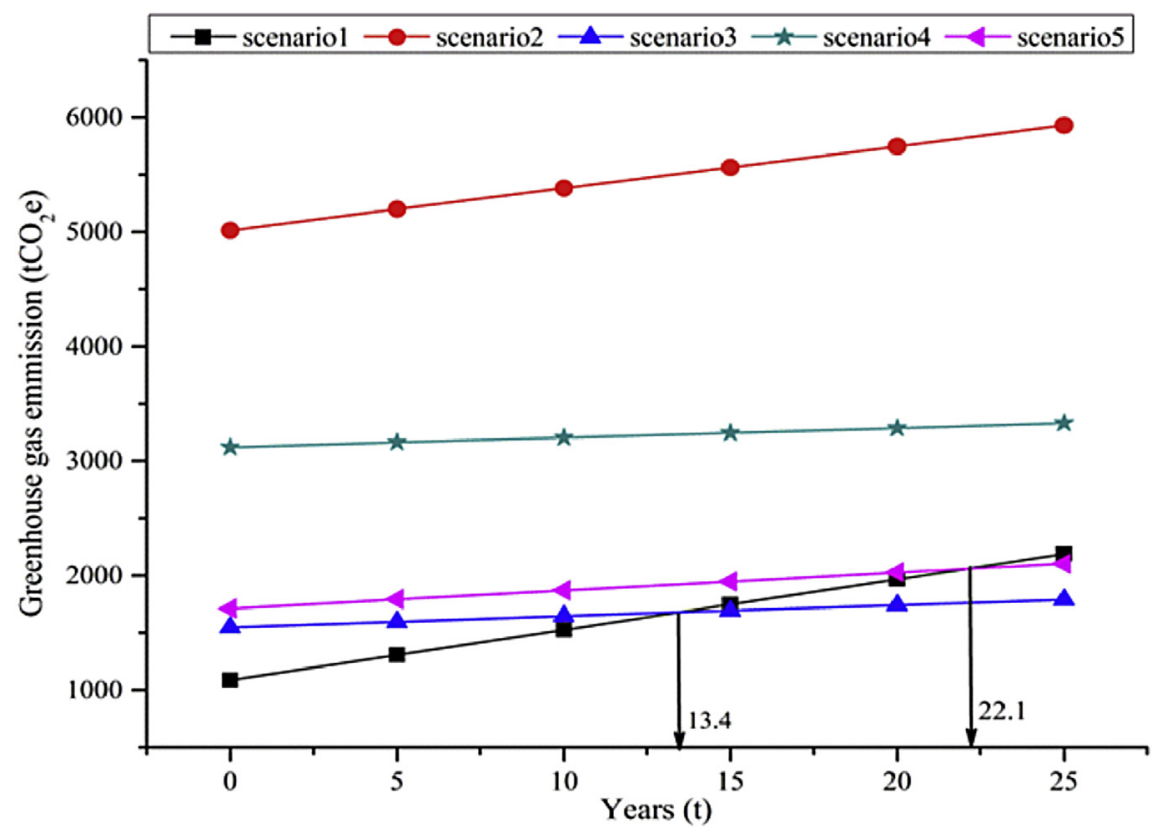

Fig. 7. Total greenhouse gas emissions in process of 25 years of the technologies.

lumping of different processes/products in to a single sector. For example, both the water and wastewater services are aggregator to the same "Production and Distribution of Water" sector, although the different water utility rate was utilized for distinction in this study, the fluctuation of water price should not be ignored.

\subsection{Impact analysis of the rising water price}

Except composting scenario, other four scenarios needed potable water service and discharged wastewater, change of water utility price played a role in selecting alternative technologies. Fig. 8 showed the effect of increased water utility prices on cash flows.
The increase in water prices increased the NPV of all alternative scenarios. In this analysis, considering the lower water price in China, supposed that the local utility rates were increased by two fold (from $1.7 \mathrm{CNY} / \mathrm{m}^{3}$ for potable water and $2.3 \mathrm{CNY} / \mathrm{m}^{3}$ for wastewater to $3.4 \mathrm{CNY} / \mathrm{m}^{3}$ for potable water and $4.6 \mathrm{CNY} / \mathrm{m}^{3}$ for wastewater). A $0 \%$ discount rate was adequate for all of the cases to show a positive NPV, except scenario 2 . With increased water utility prices, scenario 5 still had the highest NPV among all of the alternatives. The cash payback period of scenario 5 and scenario 3 decreased to approximately 3 years and 5 years, respectively. Compared to the original water price, the cash payback period of scenario 5 shortened significantly from 9 years to 3 years, on 


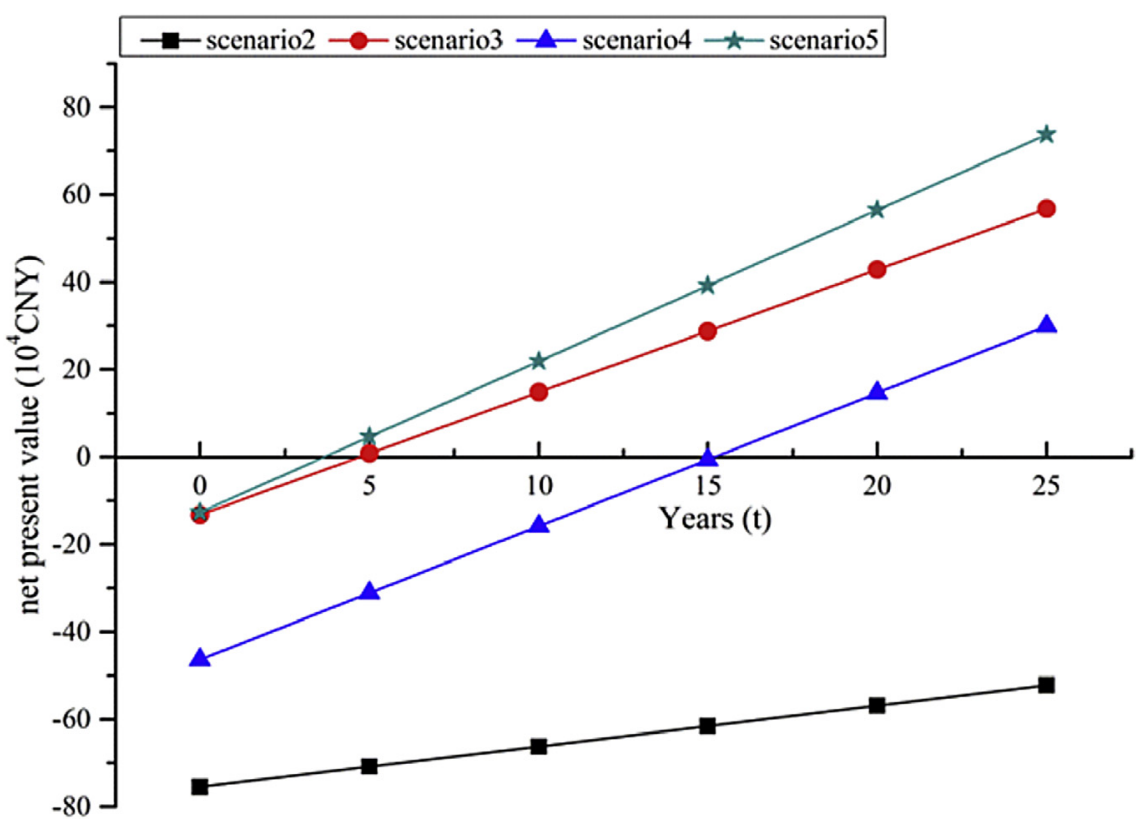

Fig. 8. Impact of the rising water prices on net present value at $0 \%$ discount rate.

account of apparent cost increase for scenario1 and negligible change for scenario 5. Furthermore, with less water consumption and wastewater discharge for scenario 4 , cash payback occurred in scenario 4 with a positive NPV at the 15 th year. The same result did not happen in scenario 2 within 25 years, although the value of NPV increased slightly. Therefore, according to our analysis, scenario 5 should be preferred over scenario 3 , and scenario 4 should be superior to scenario 2 .

\subsection{Challenges and opportunities of ecological sanitation}

Ecological sanitation (Ecosan) is a relatively new concept being promoted in many developing countries to improve sanitation coverage and recycle nutrients in excreta for agricultural production (Tumwebaze et al., 2011). Ecosan has become a primary component of the global developmental agenda (Bolaane and Ikgopoleng, 2011). This study present that potable water to flush feces and waterless urinals (senario3) and composting toilets (scenario5) should be considered as viable design options due to their better economic and environmental performance, these two alternatives had urine collected and treated separately in common, which embodied the idea of Ecosan on closing nutrient cycle. However, neither of these methods is widely accepted in practice, partially due to the deep-rooted traditional concepts of water flushing toilet, on the other hand, lack of knowledge on the installation and operation of these systems is another reason. The problem is not the method of reuse of excreta, but how to convince people to accept Ecosan's idea. Therefore, it is essential to strengthen the propaganda and education, improving residents' ecological sanitation awareness. Rainwater and composting systems are of importance especially for rural areas without sufficient wastewater treatment and those experiencing water scarcity or high fertilizer prices, necessary guidelines for the installation, use, and maintenance of these systems are important as well.

Source separation and on-site technologies are not just limited to rural area, and the novelty is that source separation can be a sustainable alternative for existing end-of-pipe systems, even in urban areas and industrialized countries. For instance, the installment of vacuum source-separation toilet makes it possible for urine diversion. This source-separation toilet reduces the burden of nitrogen and phosphorus removal in wastewater treatment plant (WWTP), the potential effect of urine-diversion toilet infrastructure has got verification in some European cities.

Rainwater is an alternative water supply that can be utilized for domestic use in urban environments. In order to ease water availability problems and decrease potable water demand, rainwater harvesting has been suggested by many researchers. It has been reported that rainwater promotes potable water savings in hotels in China (Deng, 2003), schools in Taiwan (Cheng and Hong, 2004), household multi-storey residential buildings in Germany (Herrmann and Schmida, 1999), houses in the UK (Fewkes, 1999) and others.

\subsection{System tradeoff analyses}

The present study proposes a procedure for considering multiattributes in toilet technology selection decision-making. The parameters that we examined are: cost reflecting economic feasibility, energy consumption representing resource depletion, and $\mathrm{CO}_{2} \mathrm{e}$ production representing environmental impact. In fact, it is difficult to select the most appropriate technology from among a set of available alternatives at a particular location. Many factors, except economic feasibility, resource depletion and environmental impact, are involved in the decision-making process, such as convenient maintenance, acceptability, replicability and reliability, etc. Consequently, this decision-making process may evolve a tradeoff among all of the attributes. Moreover, the decision-making process is also very sensitive toward changes of stakeholder preferences, as shown with multi-criteria decision analysis (MCDA) in the previous research, for instance, Kalbar et al. (2012) and Maurer et al. (2012) designed and evaluated the appropriateness of several feasible options for sanitation technologies in the perspective of MCDA.

Farmers are the direct beneficiaries of the construction of toilet, as well as subject of participating in the alternatives tradeoff. For this reason, we conducted a questionnaire survey and interview to local 500 farmers. After an investigation on farmer's attitudes towards the priority consideration for rural toilet technologies, we got following desired demands, ranked from most to least urgent 
Table 2

Row order of farmer's attitudes towards the priority consideration for rural toilet technologies.

\begin{tabular}{|c|c|c|c|c|c|}
\hline Number & Items & Number & Items & Number & Items \\
\hline 1 & No odors & 6 & Keeping Privacy & 11 & Zero pollution to watershed \\
\hline 2 & No flies & 7 & Lower cost & 12 & High dignity and social status \\
\hline 3 & Pathogen destruction & 8 & Easy management & 13 & $\begin{array}{l}\text { Comprehensive system having multi-function of bio-wastes recycling and renewable } \\
\text { energy generation }\end{array}$ \\
\hline 4 & Clean surroundings & 9 & Soil fertilizing & 14 & $\begin{array}{l}\text { Integrative design with multi-services such as shower, garbage disposal and } \\
\text { garden irrigation }\end{array}$ \\
\hline 5 & Convenient use & 10 & Water saving & 15 & Enjoy modern life while harmony with nature \\
\hline
\end{tabular}

and from less to more costs, the result was shown in Table 2. According to local investigation, the demand level depended on the economic, ecological and social background of the farmer. Moreover, the survey result found that low-income farmers pursued the first seven goals, while richer ones paid more attention to the last eight goals.

As far as tradeoff between traditional toilet and alternative technologies was concerned, the majority of the farmers expressed their willingness to accept the urine-diversion and potable water flushing toilet (scenario 3), as long as others were responsible for maintenance, such as storage, extraction and transport of urine. As for composting toilet, they were reluctant to cost additional capital or efforts on harmless disposal of feces, they concerned more about the effects of micro-pollutants on human health than long-term sustainability (closing nutrient cycles).

\subsection{Impact analysis of government subsidies}

The research also suggested that rainwater harvesting toilets were not dominant with respect to the economic and the environmental benefits; however, rainwater utilization is an effective method and represents a trend toward implementing sustainable water resources in the future, particularly in some areas with seasonal water deficiencies, such as the Beijing-Tianjin area in China. As public welfare projects, rainwater utilization has a longer payback period. It is difficult to achieve significant economic benefits over a short time period. From the aspect of the users, it will cause financial stress to the residents to participate in rainwater tank construction. Governments need to implement effective incentives and motivational policies to encourage estates, owners, and relevant departments or units to support rainwater utilization. This amount of government subsidy will greatly reduce the manufacturing cost of rainwater based system, which can increase the economic feasibility and provide funds to guarantee the promotion of rainwater utilization technology extension and motivation.

The problem is how much money government should offer subsidy for rainwater utilization, at least, making residents believe it economically feasible. Based on the result of NPV analysis, this study assumed four subsidy schemes for scenario 2 and 4 , that could be seen in Table 3. If residential communities construct one-toncapacity rainwater tank, 500 CNY, 1000 CNY, 1200 CNY and 1500 CNY will be supplied as rewards respectively. From Table 3, over a 25-year operational life, only when government's subsidy was 1500 CNY per ton, the NPV of both scenario 2 and 4 achieved positive comparing to standard scenario, payback periods were 12 years for scenario 2 and 18 years for scenario 4 . Scenario 2 proved infeasible on three other lower subsidy (the NPV was negative). For scenario4, the NPV began to achieve positive (6590 CNY) on the condition of 1000 CNY subsidy despite a longer payback period (23 years).

Beijing government introduced encouragement policy to promote rainwater utilization project after flood event in the summer of 2012. Government implemented relevant incentive policies to reward rainwater utilization in the coming years, offering a reward of $500 \mathrm{CNY}$ to residential communities with a rainwater storage capacity of one ton (Yin, 2012). According to the result of this study, from an economic perspective, the amount of subsidies are not enough. Therefore, some efforts must be made to strengthen policy assistance and investment for rainwater utilization by government and social organizations.

\subsection{Comparative analysis with previous relative research}

Similar to this study, Anand and Apul (2011) compared different toilet technologies on the base of economic and environmental analysis, including standard, high efficiency, rainwater flushed, and composting toilets. Although their achievement provided a methodological reference for this study, the differences are still obvious. First of all, the previous researches focused on different objects, Anand and Apul discussed on high-rise building complex in a developed country, in contrast, our study concerned countryside yard in a developing country. Moreover, regional properties determine the toilet techniques, hence, previous research placed extra emphasis on efficient low-flush toilets and surface pump pressure. Nevertheless, our study could support reference for economically viable urine-diversion toilet in rural areas. Furthermore, in our study, utilization of the Carnegie Mellon EIO-LCA software is infeasible, so it is inconceivable to indiscriminately copy the American background data on economic development and environmental situation from the existing research results. Accordingly, this study must build a model based on Chinese Economic Input-Output Table and Life Cycle Database. Unlike Anand and his colleagues, impact analysis of government subsidies for rainwater utilization is concerned in consideration as well.

\section{Conclusions}

In this study, five rural toilet alternatives, standard flushing, rainwater harvesting flushing, urine separation and composting systems were compared from the cost, energy and greenhouse gas

Table 3

Net present value and payback periods for rainwater based system on government subsidies.

\begin{tabular}{|c|c|c|c|c|c|c|c|c|}
\hline & \multicolumn{2}{|l|}{$500 \mathrm{CNY}$ ton $^{-1}$} & \multicolumn{2}{|l|}{$1000 \mathrm{CNY}$ ton $^{-1}$} & \multicolumn{2}{|l|}{$1200 \mathrm{CNY}$ ton $^{-1}$} & \multicolumn{2}{|l|}{$1500 \mathrm{CNY}$ ton $^{-1}$} \\
\hline & NPV $\left(10^{4} \mathrm{CNY}\right)$ & Years $(t)$ & NPV $\left(10^{4} \mathrm{CNY}\right)$ & Years $(t)$ & $\mathrm{NPV}\left(10^{4} \mathrm{CNY}\right)$ & Years $(t)$ & $\mathrm{NPV}\left(10^{4} \mathrm{CNY}\right)$ & Years $(t)$ \\
\hline Scenario 2 & Negative & 25 & Negative & 25 & Negative & 25 & 0.09 & 12 \\
\hline Scenario 4 & Negative & 25 & 0.659 & 23 & 0.79 & 21 & 1.06 & 18 \\
\hline
\end{tabular}


emission $\left(\mathrm{CO}_{2} \mathrm{e}\right)$ implications, The analyses were representative of a mountainous countryside for approximately 600 people in Beijing. The economic implications of the alternative scenarios were analyzed using economic net present value (NPV) calculations. Energy consumption and environment analysis were completed with the aid of EIO-LCA model based on Chinese Economic Input-Output Table and Life Cycle Database, aiming to contribute to guide the schemes selection.

From the view of economic perspective, the result found that composting systems (scenarios 5) outweighed the other four alternatives, urine-diversion and potable water flushing toilet(scenarios 3) was sub-optimal solution, even though the discount rate ranging from $0 \%$ to $10 \%$. Except these two scenarios, urinediversion and rainwater flushing toilet (scenarios 4) could be considered as alternative scenarios with the impact of rising water price, since their positive NPV. Moreover, this study suggested scenario 3 had less energy consumption, GHG emissions and a shorter environment payback period than scenario 5, proving its environmental superiority to scenario 5 . However, in the practical application, neither one of these technologies is more widely accepted than traditional flushing toilet. From local investigation, for the consideration of rural toilet technologies, farmers were more attentive to the effects of micro-pollutants on human health compared to the closing nutrient cycle. Consequently, it is essential to strengthen the propaganda and education to improve residents' awareness of ecological sanitation awareness. Meanwhile, the development of guidelines on application and maintenance is important as well.

As a significant way of sustainable water resources utilization, rainwater harvesting toilets (scenarios 2 and 4) were not dominant with respect to the economic and the environmental benefits in this study, due to the high investment in manufacturing phase, implement effective incentives and motivational policies are necessary for government to promote this technology.

\section{Acknowledgments}

This work was supported by the National Natural Science Foundation of China (No. 71273254) and Beijing special financial allocation on science and technology projects.

\section{Appendix A. Supplementary data}

Supplementary data related to this article can be found at http:// dx.doi.org/10.1016/j.jclepro.2015.12.089.

\section{References}

Anand, C., Apul, D.S., 2011. Economic and environmental analysis of standard, high efficiency, rainwater flushed and composting toilets. J. Environ Manag. 92 (3), 419-428.

Baral, A., Bakshi, B.R., 2010. Emergy analysis using US economic input-output models with applications to life cycles of gasoline and corn ethanol. Ecol. Model. 221, 1807-1818.

Belli, P., Anderson, J.R., Barnum, H.N., 2001. Economic Analysis of Investment Operations: Analytical Tools and Practical Applications. World Bank, Washington, D C.

Benetto, E., et al., 2009. Life cycle assessment of ecological sanitation system for small - scale wastewater treatment. Sci. Total Environ. 407, 1506-1516.

Berndtsson, J.C., 2006. Experiences from the implementation of a urine separation system: goals, planning, reality. Build. Environ. 41 (4), 427-437.

Bolaane, B., Ikgopoleng, H., 2011. Towards improved sanitation: constraints and opportunities in accessing waterborne sewerage in major villages of Botswana. Habitat Int. 35 (3), 486-493.

Brealey, R.A., 2012. Principles of Corporate Finance. Tata McGraw-Hill Education, McGraw-Hill, Irwin.

Chen, G.Q., Chen, Z.M., 2010. Carbon emissions and resources use by Chinese economy 2007: a 135-sector inventory and input-output embodiment. Commun. Nonlinear Sci. Numer. Simul. 15, 3647-3732.
Chen, B., Chen, S., 2013a. Life cycle assessment of coupling household biogas production to agricultural industry: a case study of biogas-linked persimmon cultivation and processing system. Energy Policy 62, 707-716.

Chen, S., Chen, B., 2013b. Net energy production and emissions mitigation of domestic wastewater treatment system: a comparison of different biogas-sludge use alternatives. Bioresour. Technol. 144, 296-303.

Chen, S., Chen, B., 2014. Energy efficiency and sustainability of complex biogas systems: a 3-level emergetic evaluation. Appl. Energy 115, 151-163.

Chen, Y., et al., 2010. Household biogas use in rural China: a study of opportunities and constraints. Renew. Sustain. Energy Rev. 14 (1), 545-549.

Chen, S., Chen, B., Song, D., 2012. Life-cycle energy production and emissions mitigation by comprehensive biogas-digestate utilization. Bioresour. Technol. 114, 357-364.

Cheng, C.L., Hong, Y.T., 2004. Evaluating water utilization in primary schools. Build Environ. 39 (7), 837-845.

China National Standardization Management Committee, 2005. Standard for Sanitary Ceramic (GB6952-2005). Standards Press of China, Beijing (in Chinese).

Chiu, Y.R., Liaw, C.H., Chen, L.C., 2009. Optimizing rainwater harvesting systems as an innovative approach to saving energy in hilly communities. Renew. Energy 34, 492-498.

Crettaz, P., J, et al., 1999. Life cycle assessment of drinking water and rain water for toilets flushing. J. Water Serv. Res. Technol. 48, 73-83.

Dallas, S., Scheffe, B., Ho, G., 2004. Reed beds for greywater treatment-case study in Santa Elena-Monteverde, Costa Rica, Central America. Ecol. Eng. 23, 55-61.

Deng, S., 2003. Energy and water uses and their performance explanatory indicators in hotels in Hong Kong. Energy Build. 35 (8), 775-784.

Egilmez, G., Kucukvar, M., Tatari, O., 2013. Sustainability assessment of U. S manufacturing sectors: an economic input output-based frontier approach. J. Clean. Prod. 53 (0), 91-102.

Esrey, S., et al., 2001. Closing the Loop Ecological Sanitation for Food Security. Swedish International Development Cooperation Agency, Mexico.

Fewkes, A., 1999. The use of rainwater for WC flushing: the field testing of a collection system. Build. Environ. 34 (6), 765-772.

Friedrich, E., Pillay, S., Buckley, C.A., 2009. Environmental life cycle assessments for water treatment processes - a South African case study of an urban water cycle. Water SA 35 (1), 73-84.

Gajurel, D.R., Li, Z., Otterpohl, R., 2003. Investigation of the effectiveness of source control sanitation concepts including pre-treatment with Rottebehaelter. Water Sci. Technol. 48, 111-118.

Gallego, A., et al., 2008. Environmental performance of wastewater treatment plants for small populations. Resour. Conserv. Recycl. 52, 931-940.

Ghisi, E., 2006. Potential for potable water savings by using rainwater in the residential sector of Brazil. Build. Environ. 41, 1544-1550.

Hendrickson, C.T., et al., 1998. Economic input-output models for environmental life-cycle assessment. Environ. Sci. Technol. 32, 184-191.

Hendrickson, C.T., Lave, L.B., Matthews, H.S., 2006. Environmental Life Cycle Assessment of Goods and Services: an Input-Output Approach. Resources for the Future, Washington, DC.

Henriques, J.J., Louis, G.E., 2011. A decision model for selecting sustainable drinking water supply and greywater reuse systems for developing communities with a case study in Cimahi, Indonesia. J. Environ. Manag. 92 (1), 214-222.

Herrmann, T., Schmida, U., 1999. Rainwater utilisation in Germany:efficiency, dimensioning, hydraulic and environmental aspects. Urban Water 1 (4), 307-316.

Hsieh, H.J., Kung, S.F., 2013. The linkage analysis of environmental impact of tourism Industry. Procedia Environ. Sci. 17 (0), 658-665.

Huang, Y., Ji, J.,P., Ma, X.M., 2012. Greenhouse gas emissions reduction from battery electric automobile: a study based on EIO-LCA model. China Environ. Sci. 32 947-953 (in Chinese).

Ji, J.P., Liu, L., Ma, X.M., 2011. Greenhouse gas emissions by Chinese economy: an assessment based on EIO-LCA model. Acta Sci. Nat. Univ. Pekin. 47, 741-749 (in Chinese).

Jiang, Q., et al., 2014a. Life cycle assessment of an engine with input-output based hybrid analysis method. J. Clean. Prod. 78 (0), 131-138.

Jiang, Q., et al., 2014b. Life cycle assessment of a diesel Engine based on an integrated hybrid inventory analysis model. Procedia CIRP 15 (0), 496-501.

Joshi, S., 1999. Product environmental life-cycle assessment using input-output techniques. J. Ind. Ecol. 3, 95-120.

Junnila, S.I., 2006. Empirical comparison of process and economic input-output lifecycle assessment in service industries. Environ. Sci. Technol. 40, 7070-7076.

Kalbar, P.P., Karmakar, S., Asolekar, S.R., 2012. Selection of an appropriate wastewater treatment technology: a scenario-based multiple-attribute decisionmaking approach. J. Environ. Manag. 113, 158-169.

Katinas, V., Markevicius, A., 2006. Promotional policy and perspectives of usage renewable energy in Lithuania. Energy Policy 34 (7), 771-780.

Katukiza, A.Y., et al., 2012. Sustainable sanitation technology options for urban slums. Biotechnol. Adv. 30 (5), 964-978.

Kirk, S.J., Dell'Isola, A.J., 1995. Life Cycle Costing for Design Professionals. McGrawHill Companies, New York.

Langergraber, G., Muellegger, E., 2005. Ecological Sanitation-a way to solve global sanitation problems? Environ. Int. 31, 433-444.

Li, X.H., et al., 2011. Life cycle greenhouse gas emission assessment of fuel ethano based on EIO-LCA. Acta Sci. Nat. Univ. Pekin. 47, 1081-1088 (in Chinese).

Lo, S.C., et al., 2005. Quantifying and reducing uncertainty in life cycle assessment using the Bayesian Monte Carlo method. Sci. Total Environ. 340 (1), $23-33$. 
Magid, J., Eilersen, A.M., Wrisberg, S., 2006. Possibilities and barriers for recirculation of nutrients and organic matter from urban to rural areas: a technica theoretical framework applied to the medium-sized town Hillerød, Denmark. Ecol. Eng. 28 (1), 44-54.

Matthews, H.S., Small, M.J., 2000. Extending the boundaries of life-cycle assessment through environmental economic input-output models. J. Ind Ecol. 4, 7-10.

Maurer, M., et al., 2012. A compatibility-based procedure designed to generate potential sanitation system alternatives. J. Environ. Manag. 104, 51-61.

Mehta, M., 2009. Water Efficiency Saves Energy, in Reducing Global Warming Pollution through Water Use Strategies. Natural Resources Defense Council New York.

Ministry of Housing and Urban-Rural Development of the People's Republic of China (MOHURD), 2014. Notification about Construction and Operation of Sewage Treatment Facilities in the Fourth Quarter of 2013. MOHURD 000013338/2014-00140. Available from: http://www.mohurd.gov.cn/wjfb/ 201403/t20140320_217412 (accessed 28.01.14.).

Montangero, A., Belevi, H., 2008. An approach to optimise nutrient management in environmental sanitation systems despite limited data. J. Environ. Manag. 88 (4), 1538-1551.

Morgan, P., 2007. Toilets that Make Compost Low-cost, Sanitary Toilets that Produce Valuable Compost for Crops in an African Context. Commission on Sustainable Development, United Nations.

Muga, H., Mukerjee, A., Mihelcic, J., 2008. An integrated assessment of the sustainability of green and built up roofs. J. Green Build. 3, 106-127.

National Economic Accounting Department of Chinese State Statistics Bureau, 2009. Chinese Input-Output Tables 2007. China Statistical Publishing House, Beijing.

Niwagaba, C., et al., 2009. Bench-scale composting of source-separated human feces for sanitation. Waste Manag. 29, 585-589.

Ortiz, M., Raluy, R.G., Serra, L., 2007. Life cycle assessment of water treatment technologies: wastewater and water-reuse in a small town. Desalination 204 (1-3), 121-131.

Otterpohl, R., 2002. Options for alternative types of sewerage and treatment systems directed to improvement of the overall performance. Water Sci. Technol. 45, 149-158.
Remy, C., Jekel, M., 2008. Sustainable wastewater management: life cycle assessment of conventional and source-separating urban sanitation systems. Water Sci. Technol. 58, 1555-1562.

Scheuer, C., Keoleian, G.A., Reppe, P., 2003. Life cycle energy and environmental performance of a new university building: modeling challenges and design implications. Energy Build. 35 (10), 1049-1064.

Stokes, J.R., Horvath, A., 2009. Energy and air emission effects of water Supply. Environ. Sci. Technol. 43 (8), 2680-2687.

Tumwebaze, I.K., et al., 2011. Ecological sanitation coverage and factors affecting its uptake in Kabale municipality, western Uganda. Int. J. Environ. Health Res. 21 (4), 294-305.

Vince, F., et al., 2008. LCA tool for the environmental evaluation of potable water production. Desalination 220, 37-56.

Vinnerås, B., Björklund, A., Jönsson, H., 2003. Thermal composting of fecal matter as treatment and possible disinfection method laboratory-scale and pilot-scale studies. Bioresour. Technol. 88, 47-54.

Wang, E., Yuan, C., 2014. A hybrid life cycle assessment of atomic layer deposition process. J. Clean. Prod. 74, 145-154.

Wang, R.S., Zhou, C.B., 2008. Ecological sanitation development in China:Potential, challenges and strategies. Chin. J. Ecol. 27 (7), 1200-1206 (in Chinese).

Wang, J.J., et al., 2014. Combined methodology of optimization and life cycle inventory for a biomass gasification based BCHP system. Biomass Bioenergy 67 (0), 32-45.

Williams, et al., 2009. Hybrid framework for managing uncertainty in life cycle inventories. J. Ind. Ecol. 13 (6), 928-944.

Winker, M., et al., 2009. Fertilizer products from new sanitation systems: their potential values and risks. Bioresour. Technol. 100, 4090-4096.

Yin, W.G., 2012-08-02. Government Introduce Encouragement Policy to Promote Rainwater Utilization Project. CHINA CONSTRUCTION NEWS.

Zhang, Z., Wilson, F., 2000. Life-cycle assessment of a sewage-treatment plant in South-East Asia. J. Inst. Water Environ. Manag. 14, 51-54.

Zhou, C.B., et al., 2008. Adaptive optimized technologies for ecological sanitation and their complex ecological benefits. Chin. J. Appl. Ecol. 19 (2), 387-393 (in Chinese).

Zhou, C.B., et al., 2010. Ecological-economic assessment of ecological sanitation development in the cities of Chinese Loess Plateau. Ecol. Complex. 7, 162-169. 